\title{
Pewarisan ilmu dukun dalam sistem penyembuhan tradisional
}

\author{
Shamanic power inheritance in traditional healing system
}

\author{
Nur Ika Anisa' Ul Jannah \& Siti Zurinani \\ Program Studi Antropologi, FIB, Universitas Brawijaya, Malang \\ Jalan Veteran, Ketawanggede, Kec. Lowokwaru, Kota Malang, Jawa Timur 65145 \\ Telepon: (0341) 575875 \\ E-mail: nurikaanisa8@gmail.com
}

\begin{abstract}
People in Sidodadi village believe that shaman and their shamanic power have ability to heal health problems. However, a shaman is usually reluctant to be called 'shaman' since the term of shaman is highly associated with a form of black magic. They prefer to be called 'tyang saget'(capable people). This research focuses to describe shamanic power inheritance within shaman practice in Sidodadi village. Understanding the shamanic power inheritance is part of the way to understand reasons of people of Sidodadi who still believe in shaman. This research was conducted in Sidodadi village, in north Banyuwangi, East Java. This research used snowball sampling technique to enrich qualitative data and to strengthen the argument. Data gathered by direct observation of shaman related activities of Sidodadi people. Thus, data analyzed used descriptive ethnographic method. The result shows that familial ties dominate the shamanic power inheritance. There is a cycle where shaman in Sidodadi transfers their knowledge to their descendant whom believed would take the role as shaman in the future.
\end{abstract}

Keywords: traditional healing, dukun, knowledge transfer, faith

\begin{abstract}
Abstrak
Masyarakat di Desa Sidodadi menjadikan dukun sebagai penyembuh kesehatan mereka. Seorang dukun penyembuh enggan dikatakan sebagai dukun melainkan pujonggo maupun tyang saget karena istilah dukun tanpa embel-embel penyembuh akan mengarah pada dukun ilmu hitam. Penelitian fokus untuk mendeskripsikan pewarisan ilmu dukun penyembuh yang telah berlangsung di kerabat dukun. Pewarisan ilmu dukun tersebut sebagai suatu upaya untuk mendeskripsikan kelanggengan ilmu dukun penyembuh di Desa Sidodadi. Lokasi penelitian yang dipilih adalah di Desa Sidodadi, Banyuwangi Utara. Peneliti menggunakan teknik snowbal sampling dengan beberapa tahap bertemu dengan informan. Cara pengumpulan data dilakukan dengan pengamatan secara langsung kegiatan perdukunan di masyarakat Desa Sidodadi. Analisis data dilakukan secara deskriptif etnografik, yakni berusaha mendeskripsikan subjek penelitian dan cara mereka bertindak dan berkatakata. Hasil penelitian ini menunjukkan bahwa pewarisan ilmu perdukunan yang didominasi oleh keturunan. Terdapat siklus di mana dukun di Desa Sidodadi menerapkan pengetahuan perdukunannya kepada anak-anaknya atau keturunannya, yang kemudian dipercayai oleh generasinya dalam bentuk mitos dan praktik pengobatan yang dimiliki keluarga terdahulunya.
\end{abstract}

Kata kunci: budaya penyembuhan, dukun, pewarisan ilmu, kepercayaan

\section{Pendahuluan}

Masyarakat Desa Sidodadi memiliki sebuah adat dan kebudayaan sendiri ketika menghadapi sebuah kondisi sehat maupun sakit. Masyarakat dengan pengetahuan dan pengalaman kesehatan tradisional yang masih kuat, menjadikan dukun sebagai penyembuh kesehatan mereka. Pelly (1989) dalam Sianipar (1989) mengatakan tingkah laku manusia dalam menghadapi masalah kesehatan bukanlah suatu tingkah laku yang acak (random behavior), tetapi suatu tingkah laku yang selektif, terencana, dan terpola dalam suatu sistem kesehatan yang merupakan bagian integral dari budaya masyarakat yang bersangkutan. Senada dengan pernyataan Pelly (1989) dalam Sianipar (1989), bahwa pemilihan penyembuhan kepada dukun merupakan bagian dari kepercayaan yang dibudayakan, khususnya mengenai kepercayaan rakyat setempat yang juga mendorong kuatnya kepercayaan terhadap peran seorang dukun sehingga dalam penyembuhan penyakit dukun masih diminta tolong sebagai tenaga penyembuh utama maupun alternatif. 
Masyarakat desa menganggap istilah dukun dengan dua keilmuan yaitu ilmu penyembuhan dan ilmu mencelakai orang. Seorang dukun penyembuh enggan dikatakan sebagai dukun melainkan pujonggo maupun tyang saget karena istilah dukun tanpa embel-embel penyembuh akan mengarah pada dukun ilmu hitam. Ilmu penyembuhan yaitu ilmu yang dimiliki oleh seorang dukun penyembuh untuk penyembuhan penyakit. Ilmu mencelakai orang yaitu ilmu yang dimiliki oleh dukun santet (sihir) maupun dukun lintrik (guna-guna) untuk melakukan kesialan kepada orang yang dibenci atau didengki oleh pasiennya. Santet digunakan untuk mencelakakan seseorang melalui teluh yang dikirim si dukun kepada korbannya sesuai permintaan pasiennya, sehingga korban teluh tersebut jatuh sakit secara fisik. Dukun lintrik yakni dukun yang menggunakan mantra pengikat rayuan kepada korban si dukun. Mantra tersebut digunakan di beberapa media seperti bedak dan minyak rambut yang dipakai si pasien dukun. Umumnya, lintrik digunakan untuk menghancurkan rumah tangga seseorang dengan menggangu kejiwaan korban agar terus teringat kepada pengguna lintrik tersebut.

Sianipar (1989) bahwa dukun sihir dan dukun guna-guna memelihara sebangsa jin yang sewaktuwaktu dapat disuruh untuk membawa guna-guna dan memasukannya ke tubuh seseorang. Ia tidak segan menyakiti orang lain dengan ilmu atau keahlian yang dimilikinya. Ilmu untuk mencelakai orang dan mengganggu kejiwaan korban tersebut dapat disembuhkan oleh dukun penyembuh namun, tidak semua dukun penyembuh di Desa Sidodadi yang dapat menyembuhkan kedua ilmu tersebut, melainkan seorang dukun penyembuh yang memiliki kekuatan ngelmu ghaib dapat melakukan penyembuhan tersebut.

Dukun penyembuh di Desa Sidodadi terdiri dari pujonggo atau wong tuwek, tiyang saget, dukun gambuh, dukun bayi dan dukun pijat. Selain sebagai tenaga penyembuh, seorang dukun juga diminta sebagai pemimpin perayaan ritual adat. Penyembuhan tradisional dan ritual adat di Desa Sidodadi masih berhubungan erat dengan kepercayaan rakyat. Danandjaja (2002) bahwa kepercayaan rakyat yang berhubungan dengan tahayul dan mitos dasar dilakukannya ritual adat untuk mencapai keselamatan hidup. Kepercayaan rakyat atau cerita takhayul di Desa Sidodadi berlaku tidak hanya sebagai cerita lisan tetapi sebagai penuturan norma dan nilai adat yang dipercaya melalui cerita ilok (pantas) dan ga ilok (tidak pantas).

Pengetahuan mengenai sehat dan sakit masyarakat Desa Sidodadi dipengaruhi oleh kesehatan batiniah dan rohaniah. Kesehatan batiniah dikarenakan oleh stabilnya daya tahan tubuh (naturalistik) sedangkan keselamatan rohaniah dikaitkan dengan akibat ilmu guna-guna atau ilmu santet serta sebab dan akibat dari gangguan barang alus yang kemudian menyebabkan sakit (personalistik). Hal tersebut selaras dengan yang dikatakan Foster dan Anderson (1986), bahwa persepsi timbulnya suatu penyakit di kalangan masyarakat, sering dikaitkan dengan adanya dua konsep yaitu konsep Naturalistik dan konsep Personalistik. Penyebab bersifat Naturalistik yaitu seseorang menderita sakit akibat pengaruh lingkungan, makanan (salah makan), kebiasaan hidup, ketidakseimbangan dalam tubuh, termasuk juga kepercayaan panas dingin seperti masuk angin dan penyakit bawaan, sedangkan konsep Personalistik menganggap munculnya penyakit (illness) disebabkan oleh intervensi suatu agen aktif yang dapat berupa makhluk bukan manusia (hantu, roh, leluhur atau roh jahat), atau makhluk manusia (tukang sihir, tukang tenung).

Pujonggo mewariskan ilmu perdukunan kepada keturunannya dengan berbagai variasi pewarisan. Pewarisan ilmu dukun yang dilakukan oleh pujonggo tidak sebatas tentang penyembuhan, namun juga pengetahuan-pengetahuan yang berhubungan dengan kepercayaan adat, seperti ritual slametan. Penyembuhan dan ritual adat dipercaya sebagai bentuk kesehatan dan keselamatan hidup dari penyakit dan karma. Seorang dukun penyembuh di Desa Sidodadi dengan ngelmu yang kuat mampu menangani berbagai penyakit dan ritual adat. Selebihnya dukun hanya memiliki kemampuan terbatas seperti penanganan kelahiran bayi dan pijat tanpa dapat memimpin upacara adat.

Pewarisan ilmu perdukunan di Desa Sidodadi tidak serta merta dapat dipelajari dan dipraktikkan oleh seorang calon dukun. Syarat-syarat khusus diberikan oleh sesepuh dukun kepada calon dukun. Syarat tersebut terkait dengan kemampuan ngelmu yang dianut seorang dukun dan syarat praktik perdukunan yang sudah pakem dipercaya secara turun temurun. Pujonggo mewariskan ilmu perdukunannya 
dengan proses yang bervariasi. Setiap dukun yang telah diwarisi ilmu perdukunan memiliki kemampuan yang berbeda-beda sesuai dengan minat dan kemampuan ngelmu yang dilakukannya dalam suatu ritual perdukunan.

Penelitian ini untuk mendeskripsikan pewarisan ilmu dukun penyembuh yang telah berlangsung di kerabat dukun. Pewarisan ilmu dukun tersebut sebagai suatu upaya untuk mendeskripsikan kelanggengan ilmu dukun penyembuh di Desa Sidodadi. Pada pembahasan penelitian terdahulu pelanggengan praktik perdukunan lebih ditekankan eksistensi dan pengobatannya pada lingkup kota yakni Kota Makasar, seperti dalam penelitian Syuhudi (2013), sedangkan penelitian ini berada di lingkup desa yang masih menggunakan pewarisan perdukunan melalui religiusitas dan sistem kekerabatannya. Penelitian kedua dilakukan oleh Rienks dan Iskandar (1985) menjelaskan praktek perdukunan yang lebih banyak menguraikan peran dukun dalam penyembuhan tradisional serta dualisme pengobatan medis dan tradisional yang mengkaitkan dukun dan bidan. Rienks dan Iskandar (1985) mengkaitkan budaya Jawa dalam tingkatan ilmu perdukunan dan penyembuhan penyakit, tetapi tidak menerangkan bagaimana tingkatan dukun dan pewarisan ilmu dukun tersebut diwariskan serta tidak disebutkan mengenai pengaruh kepercayaan setempat pada penyakit.

Penelitian ketiga dilakukan oleh Alwisol (1989) mengenai pengobatan penyakit dipengaruhi oleh agama maka di Desa Sidodadi penyakit dipengaruhi oleh kepercayaan dan keyakinan masyarakat yang terpengaruh oleh budaya mistis Jawa. Alwisol (1989) juga memusatkan kebudayaan tradisional untuk penyembuhan, mengembangkan point tersebut penelitian ini memasukan unsur kepercayaan rakyat atau cerita takhayul dalam pengobatan penyakit di Desa Sidodadi. Penelitian lain mengenai sanro atau dukun di kota Makasar dilakukan oleh Sianipar (1989) yang mengulas mengenai pewarisan dukun dari proses sakit keras, gangguan jiwa, dan mengalami kematian sedangkan peran dan proses pewarisan perdukunan di Desa Sidodadi berlangsung dari kepercayaan masyarakat yang berkembang menjadi penyokong penyembuhan tradisional setempat serta tanpa fase yang disebut oleh Sianipar (1989).

Penyembuhan tradisional di Desa Sidodadi dilakukan oleh para sesepuh adat, salah satunya dukun. Dukun dalam hal ini yakni pelaku pengobatan tradisional di masyarakat yang dipercayai dalam melakukan penanganan penyakit dan penasehat kesehatan. Seorang dukun di Desa Sidodadi memiliki kemampuan yang bervariasi sesuai dengan ilmu dan ritual yang ditradisikan. Penelitian ini merumuskan masalah mengenai pewarisan ilmu perdukunan yaitu bagaimana pewarisan ilmu dukun dalam sistem penyembuhan tradisional di Desa Sidodadi?

\section{Metode Penelitian}

Lokasi penelitian yang dipilih adalah di Desa Sidodadi, Banyuwangi Utara. Desa Sidodadi tidak memiliki bangunan rumah sakit namun telah ada rumah-rumah bidan dan dukun penyembuh yang membantu masyarakat sekitar. Pemilihan lokasi di Desa Sidodadi terkait dengan budaya masyarakat yang memiliki tiga budaya berbeda, Jawa, Osing dan Madura yang mempengaruhi ritual perdukunan seperti mantra yang dimiliki dukun dan istilah-istilah penyembuhan penyakit. Selain di Desa Sidodadi, Banyuwangi bagian selatan juga terkenal dengan ilmu perdukunannya seperti Kecamatan Rogojampi dan Licin namun unsur budaya lingkungan sekitar yakni Osing sehingga segala ritualnya berdasarkan mantra dan ritual Osing. Fokus daerah penelitian diambil di Desa Sidodadi yang mempunyai 3 budaya dengan fokus pewarisan dukun meliputi ritual perdukunan dan ritual penyembuhan yang dilakukan oleh si dukun.

Masyarakat Desa Sidodadi masih percaya terhadap makhluk halus di daerah-daerah yang dianggap sintru atau angker. Kepercayaan terhadap daerah-daerah yang dianggap sintru atau angker tersebut dikarenakan Desa Sidodadi masih berbatasan langsung dengan sawah, sungai, dan corah. Masyarakat yang mempercayainya akan melarang anak-anak mereka untuk bermain di tempat-tempat yang dianggap angker pada waktu-waktu tertentu seperti suwung dan siang hari (waktu dhuhur). Larangan tersebut akan dikaitkan dengan keganasan Batharakala dan penyakit kesambet. 
Informan yang dipilih oleh peneliti yaitu pelaku kesehatan tradisional di Desa Sidodadi yang telah terenkulturasi oleh budaya perdukunan. Informan diharapkan telah memahami dan masih terlibat budaya perdukunan tersebut sehingga informasi yang akan digali dari permasalahan budaya dapat diantisipasi dan dipahami. Seorang dukun yang sekaligus memahami mitos kesehatan dan perdukunan menjadi informan penting yang dapat menjelaskan budaya perdukunan di Desa Sidodadi.

Peneliti juga menggunakan teknik snowball sampling dengan beberapa tahap bertemu dengan informan. Pertama-tama peneliti menemui Pak Sidik selaku kaur desa, kepada beliau peniliti mengutarakan maksud penelitian dan menanyakan informan terkait penelitian perdukunan. Pak Sidik mengarahkan untuk berkunjung ke rumah Mbah Katiyah, Mbah Sogol dan Mbah Saprak yang dianggap sebagai tetua dukun atau wong tuwek di Desa Sidodadi. Arahan dari informan satu kepada informan lain yang dianggap telah terenkulturasi penuh tentang ngelmu perdukunan. Informan tersebut mengarah pada ketiga dukun yang telah disebutkan di atas.

Ketika berkunjung ke rumah Mbah Katiyah, si mbah menceritakan bahwa memiliki tujuh anak dan dua cucu yang menjadi dukun yaitu Mbah Sogol dan Pak Imam sehingga Mbah Sogol juga menjadi informan penelitian. Setelah itu, peneliti juga menanyakan kepada masyarakat sekitar (Mbak Rita, Mbak Siti dan Mbak Subi) mengenai keberadaan dukun penyembuh di Desa Sidodadi. Mbak Subi juga merekomendasikan kepada salah satu dukun yang dapat menangani kesurupan yaitu kepada Pak Sudir.

Ketika ditemui di rumahnya, Pak Sudir mengatakan dirinya belum bisa menjelaskan penuh bagaimana proses ngelmu perdukunan karena dalam penjelasan mengenai hal yang dianggap sakral lebih dipahami oleh sesepuhnya yaitu Pak Mad, Mbah Katiyah dan Mbah Sogol. Tanggapan Pak Sudir tersebut diakui sebagai penghormatan kepada yang lebih sepuh mengenai cara-cara ngelmu perdukunan. Pemahamannya sebagai dukun dirasa lebih sempurna guru pembimbingnya tersebut dalam artian Pak Sudir memahami bahwa dirinya belum terakulturasi penuh mengenai ngelmu perdukunan. Beliau mengatakan dalam bahasa sehari-harinya,"Corone diibaratne wong mangan manis ikisak manis-manise aku, sek manisan wong tuwek. Wong tuwek ku sek isek. Seperguruan tapi tuwek an nang kono. Coronye buah enek seng lebih tuwek" (Ibarat makan manisan. Semanismanisnya saya, masih manisan orang yang lebih tua. Orang tua masih ada. Seperguruan tapi lebih tua sana. Seperti makan buah ada yang lebih tua).

Pak Sudir mengira peneliti akan meminta ilmu perdukunan sehingga dirinya mengarahkan kepada dukun sepuh yang dianggap lebih memahami ilmu perdukunan (mantra). Setelah penjelasan lebih rinci akhirnya Pak Sudir menanggapi pertanyaan-pertanyaan peneliti untuk mengulas pengalaman perdukunan beliau. Setelah dari Pak Sudir, peneliti berkunjung ke rumah Mbah Saprak seorang dukun pijat di Desa Sidodadi. Mbah Saprak juga memberikan saran untuk datang ke rumah Mbok Endi, Bu Rum dan Pak Zainul.

Cara pengumpulan data dilakukan dengan pengamatan secara langsung kegiatan perdukunan di masyarakat Desa Sidodadi. Penulis juga melakukan wawancara mendalam kepada 1 orang dukun di antaranya kasepuhan, 2 tyang saget, 1 orang dukun gamboh, 3 dukun pijat, 1 tukang pijat dan 1 calon dukun. Wawancara juga dilakukan dengan 3 masyarakat sekitar untuk melihat peranan dukun. Wawancara mendalam dilakukan guna mendapatkan informasi sehubungan dengan proses regenerasi dukun.

Peneliti melakukan observasi (pengamatan). Pengamatan adalah suatu penyelidikan sistematis menggunakan kemampuan indera manusia. Pengamatan dapat dilakukan saat terjadi aktiftas budaya dan wawancara mendalam. Pengamatan dibagi menjadi pengamatan berperan serta dan pengamatan tidak berperan serta (Endraswara 2003). Dalam hal ini peneliti melakukan proses pengamatan tidak berperan serta. Pengamatan dilakukan pada saat penulis melihat pemijatan, perayaan ritual adat pernikahan, dan jaranan baik dari persiapan hingga akhir ritualnya yang dilakukan oleh masingmasing dukun dalam ahlinya. Pada kegiatan pengamatan ini penulis dapat mengetahui proses dan interaksi yang terjadi antara dukun dan masyarakat. 
Peneliti juga melakukan wawancara terbuka. Wawancara terbuka adalah penulis dan yang diteliti sama-sama tahu dan tujuan wawancara pun diberitahukan (Endraswara, 2003). Peneliti melakukan wawancara mendalam kepada pujonggo hingga calon dukun dan masyarakat setempat dengan mengemukakan maksud dan tujuan penelitian. Peneliti membuat rancangan pedoman wawancara sebagai acuan ketika melakukan wawancara, namun tidak menutupi kemungkinan pertanyaan di dalam pedoman menyesuaikan saat wawancara dilakukan.

Teknik pengambilan data berikutnya adalah dengan cara studi literatur. Studi literatur ini dilakukan untuk mengetahui gambaran umum tentang monografi desa. Studi literatur juga dapat digunakan untuk memperoleh informasi atau data mengenai topik permasalahan yang dibahas dari buku referensi, dokumen, maupun jurnal terkait.

Pendekatan etnografi yang digunakan dalam penelitian ini mengacu pada model pendekatan emik, yakni memandang fenomena-fenomena sosial budaya atas dasar sudut pandang masyarakat yang menjadi objek kajian, yakni dukun-dukun kesehatan setempat dan pasien mereka. Penelitian ini juga menggunakan pendekatan etnografi yang bersifat holistik-integratif, yang bertujuan untuk mendapatkan data atas dasar native's point of view (Spradley 1997).

Analisis data dilakukan secara deskriptif etnografik, yakni berusaha mendeskripsikan subjek penelitian dan cara mereka bertindak dan berkata-kata. Analisis data juga dilakukan dengan menelaah seluruh data yang tersedia dari berbagai sumber, yaitu hasil wawancara, catatan lapangan, dokumendokumen, dan lain-lain. Setelah itu mereduksi data, memaparkan data dan simpulan melalui pelukisan dan verifikasi (Endaswara 2003).

\section{Hasil Penelitian dan Pembahasan}

Pembagian dukun di Desa Sidodadi berdasarkan keilmuannya terdapat ilmu hitam dan ilmu putih. Pembagian istilah dukun ilmu hitam terdiri dari dukun santet, guna-guna dan lintrik sedangkan dukun ilmu putih didasarkan pada tujuan penyembuhan dan penyelenggara ritual adat. Ketika menyebutkan istilah dukun, masyarakat akan menanyakan dukun apa yang dimaksud, hal tersebut merupakan dua pemahaman berbeda antara dukun ilmu hitam dan putih. Istilah dukun atau jenges lebih mengarah pada dukun ilmu hitam, baik itu santet, lintrik dan guna-guna, sedangkan dukun penyembuh diistilahkan dengan pujonggo (wong tuwek) dan tiyang saget.

Dukun santet dipercayai sebagai dukun untuk mencelakai seseorang melalui teluh, panah tae, dan benda kiriman lainnya. Dukun lintrik hampir memiliki kesamaan dengan dukun guna-guna akan tetapi dukun lintrik memiliki media yakni kartu atau tarot yang digunakan untuk memikat orang lain kepada pasiennya bahkan membuat gila atau gangguan jiwa (kedanan) dan stres (ngelayung) pada korban ketika terpikat pesona pasiennya melalui jampe-jampe yang ditaruh di bedak, minyak wangi maupun minyak rambut.

Spesifikasi dukun penyembuh di Desa Sidodadi terbagi menjadi lima yaitu yang dikenal sebagai pujonggo. Pujonggo atau wong tuwek mewariskan variasi ilmunya kepada tiyang saget dan tukang pijat melalui proses yang bervariasi pula. Pujonggo (wong tuwek) dianggap memiliki ilmu perdukunan yang lebih tinggi dibandingkan tingkat perdukunan yang lainnya yakni dengan pengalamannya menyembuhkan orang (kemujaraban) serta pengetahuannya mengenai ilmu perdukunan. Pujonggo (wong tuwek) juga memiliki ritual untuk berhubungan dengan kekuatan supranatural. Kekuatan supranatural di sini dipahami sebagai roh-roh halus ataupun nenek moyang yang sudah meninggal yang membantu peningkatan ilmu perdukunan. Kedua yaitu tiyang saget. Kata tiyang (Bahasa Jawa) dan reng (Bahasa Madura) memiliki arti orang dan saget berarti yang mampu (memiliki kemampuan). Tiyang saget atau dukun petunjuk kerap diminta tolong oleh masyarakat dalam hal ritual seperti membangun rumah, pernikahan, pawang hujan dan selametan. Kerap kali julukan tiyang saget juga dilengkapi dengan bidang pertolongan yang dilakukan oleh si dukun tersebut seperti pawang hujan, nemokne manten dan perhitungan Jawa-Madura. 
Ketiga yaitu Dukun gambuh. Dukun gambuh merupakan dukun dalam lingkup kesenian semisal kesenian jaranan atau kuda lumping. Dukun gambuh di Desa Sidodadi menjadi pelaksana dalam kesenian jaranan dan sebagai pawang dari para pemain kesenian tersebut. Bermula dari pemotongan janur yang dilakukan oleh pemilik hajat dipandu oleh dukun gambuh, hal tersebut menandakan dimulainya pertunjukan kesenian jaranan. Kemudian dukun gambuh memberikan mantra-mantra kepada anggota jaranan yang akan melakukan pertunjukan. Konon dipercaya mantra tersebut mengundang roh-roh halus dan menjadikan pemain-pemain jaranan tersebut lupa diri atau ndadi seiring dimainkannya musik gamelan.

Dukun gambuh tidak hanya menjadi pawang dalam kesenian jaranan, melainkan juga mengatasi orang-orang yang kesurupan atau kerasukan. Kesenian jaranan mengundang "barang alus" untuk merasuki pemainnya dan juga dapat merasuki orang-orang di luar pemain. Dalam penanganannya, Pak Sudir melakukan percakapan untuk mengusir barang alus tersebut. Selain itu juga diperlukan kelengkapan sajen (pepak sajen) yang digunakan untuk melengkapi ritual agar tidak mengganggu atau merasuki penonton, karena ketika sajen tersebut tidak lengkap barang alus tersebut akan marah dan mengganggu aksi pertunjukan maupun pengusiran roh halus.

Keempat Dukun bayi. Dukun bayi merupakan seorang dukun yang kerap diminta menangani permasalahan bayi. Permasalahan bayi yang ditangani oleh Dukun bayi yaitu proses kelahiran, selametan bayi, pijat bayi, mandi bayi, dan permasalahan ibu pasca melahirkan dan menyusui. Biasanya Dukun bayi membantu perawatan bayi dari lahir hingga selapanan atau 40 hari usia bayi. Spesifikasi ilmu perdukunan di Desa Sidodadi kerap kali dapat merangkap perannya, seperti seorang tyang saget yang memiliki berbagai ilmu pengobatan tradisional dapat memijat, suwok maupun gambuh. Sedangkan tukang pijet kerap kali hanya memiliki kemampuan untuk memijat. Menurut Mbah Katiyah, suwok merupakan obat melalui doa dengan menggunakan peritungan hari Jawa (kliwon, legi, pahing, pon, wage) dan dicocokan dengan hanacaraka, untuk melihat penyakit dan penyembuhannya. Terdapat beberapa macam pengobatan suwuk yang dipercaya oleh masyarakat Desa Sidodadi yaitu Suwuk Kolomonggo (pemberian doa adas kulo waras, kemudian binatang kolomonggo dihaluskan dan diusapkan ke tempat yang sakit) selain kolomonggo juga dapat menggunakan binatang kroco yang dihaluskan dan diberi gula. Suwuk kayuwatu untuk meredakan penyakit pusing kepala dan suwuk yangjiwangjahung untuk mengobati sakit perut.

Keyakinan terhadap kekuatan gaib yang suci, agama islam, dan adat setempat merupakan keseimbangan yang dikemas pada ritual perdukunan. Dukun di Desa Sidodadi akan menerngkan bahwa mereka memeluk agama islam, tetapi sebagian mereka mencampuradukan konsep kebatinan Jawa dalam kehidupan beragama. Islam diakui dengan lima rukunnya namun kebatinan juga masih dilakukan dalam ritual pemujaan leluhur seperti sandingan dan acara selametan. Selain itu dukun di Desa Sidodadi percaya akan adanya mitos, sakit, makhluk halus (barang alus), leluhur, keramat, jimat dan persembahan Hal ini menandakan bahwa sinkretisme dilakukan oleh dukun di Desa Sidodadi dalam ritual perdukunannya.

Pada prakteknya, setiap dukun memiliki dasar ilmu yang menuntun rutinitas perdukunannya seperti ritual, doa, primbon maupun praktek yang dipercaya sesuai ajaran pujonggo terdahulunya. Primbon merupakan catatan yang menyangkut masalah aturan-aturan, pedoman, dan petunjuk peri kehidupan dan perilaku yang berlaku di masyarakat Jawa, Subalidinalita (1985) dalam Kasnodihardjo (2012). Primbon juga masih dipercaya oleh pujonggo, tyang saget dan penyembuh tradisional lainnya desa sebagai sumber acuan penggunaan rapal. Akan tetapi tidak semua primbon yang beredar di pasaran dapat menjadi acuan yang berisikan tata cara ngelmu perdukunan melainkan beberapa primbon yang memang dianggap sebagai sumber akurat meskipun keberadaan primbon yang dimaksud sudah tidak lagi beredar.

\section{Proses Pewarisan Ngelmu Perdukunan}

Seseorang yang memiliki ilmu pengobatan tradisional dan menjadi tokoh penyelenggara ritual adat di Desa Sidodadi kerap kali tidak mengatasnamakan dirinya sebagai seorang dukun. Tokoh tersebut 
hanya mengatasnamakan sebagai penolong "wong seng iso nulungi". Istilah dukun dan macammacamnya seperti yang telah dijelaskan sebelumnya merupakan istilah yang diberikan oleh masyarakat kepadanya. Tidak ada tanda khusus yang dapat menandai dirinya sebagai dukun, tidak ada kartu identitas dan juga tidak ada plakat yang menandakan praktik kerja dukun di rumahnya.

Syarat menjadi seorang dukun harus memiliki keyakinan (niat dan tekat) dalam batinnya. Pada saat menjalani tirakat dirinya harus benar-benar memfokuskan pikiran dan batinnya untuk mencapai kekhusukan dalam melaksanakan ritual. Penduduk Desa Sidodadi tidak bisa begitu saja menjadi seorang dukun, kecuali telah melewati batas usia dan kemampuan melakukan ritual ngelmu perdukunan yang membutuhkan kesiapan batin dan fisik. Beberapa pendukung seseorang dapat menjadi seorang dukun di Desa Sidodadi yaitu melalui pewarisan berdasarkan keturunan dan juga berguru. Berbeda dengan penelitian sebelumnya yang mengatakan proses ilmu perdukunan dapat terjadi melalui mimpi, penyakit keras, bahkan mengalami kematian. Tidak seekstrim hal tersebut, akan tetapi di Desa Sidodadi cukup dengan melalukan kebiasaan yang kerap dilakukan oleh Buyut, Kakek dan Nenek yang telah diajarkan kepada keluarganya sehingga tindakan-tindakan penyembuhan dan mitos lisan terjadi dalam keluarga. Kebiasaan berguru mengenai ngelmu perdukunan kepada kyai maupun wong tuwek menjadi suatu kebiasaan yang harus tetap dijaga. Kebiasaan tersebut dipraktikkan secara berulang-ulang setiap harinya.

Yusuf (1989) menjelaskan mengenai perilaku manusia berkaitan dengan (1) tujuan, harapan, (2) pengalaman masa lampau, (3) sistem kepercayaan, (4) nilai sosial dan (5) struktur sosial. Pada konsepnya mengenai peran perilaku penyembuh kesehatan tersebut dapat dipahami bahwa setiap dukun memiliki tujuan untuk mempertahankan ilmu yang dia miliki, salah satunya dengan proses pewarisan ilmu perdukunan.

Setiap orang memiliki orientasi sehat dan selamat, tak terkecuali di masyarakat Desa Sidodadi. Masyarakat memiliki harapan yang dipercayakan kepada seorang dukun sebagai penyembuh dan pelaksana ritual adat mereka. Sebagai seorang dukun harapan dalam pewarisan ilmu perdukunan sebagai cara melanggengkan pengetahuan-pengetahuan perdukunan kepada pewarisnya untuk dapat menyembuhkan sakit yang dialami keluarga maupun masyarakat sekitar. Pewarisan ilmu perdukunan juga sangat berhubungan dengan pengalaman masa lampau, sistem kepercayaan dan nilai sosial yang telah menjadi adat istiadat masyarakat setempat. Masa lampau dalam hal perdukunan sangat berpengaruh pada proses pewarisan dukun yang mana pemahaman ngelmu perdukunan rupanya berawal dari keturunan terdahulu. Kebiasaan-kebiasaan nenek moyang dalam proses penyembuhan telah diwariskan sehingga banyak seorang dukun yang memahami praktik perdukunan berasal dari keluarga. Pengalaman masa lampau juga terlihat dari kepercayaan jodo terhadap penyembuhan penyakit oleh seorang dukun yang dipercaya masyarakat di Desa Sidodadi.

Dukun sepuh dan tyang saget di Desa Sidodadi memiliki ilmu ghaib yang digunakan untuk menyembuhkan penyakit personalistik dari guna-guna, kesurupan dan sawan dengan menggunakan mantra, jimat dan ritual pengalihan barang alus. Selain itu dalam penyembuhan penyakit naturalistik melalui pengobatan tradisional dengan menggunakan ramuan resep nenek moyang dan memijat atau mengurut pada bagian tubuh. Namun kerap dijumpai juga, penyembuhan dengan menggunakan cara keduanya.

Sistem kepercayaan juga digunakan dalam mendiagnosis penyakit yang diderita pasien dukun, khususnya yang berhubungan dengan mitos setempat seperti kesambet. Menurut masyarakat setempat kesambet yaitu akibat dari kemarahan barang alus yang tidak suka tempatnya dikotori, sehingga menyebabkan penyakit.

Sistem kepercayaan seorang dukun juga dapat dilihat dari kekuatan religiusitas yang berhubungan dengan laku ritual ngelmu perdukunan. Dukun di Desa Sidodadi sebagian besar memiliki kekuatan spiritual yang dipercaya dapat memperlancar atau membantu penyembuhan penyakit. 
Kekuatan spiritual tersebut didapatkan dari bantuan roh leluhur yang dianggap sebagai penuntun ilmunya. Selain bantuan roh leluhur juga dari keteguhan dalam perilaku ngelmu ritual perdukunan. Ritual-ritual pewarisan tersebut salah satunya adalah melalui tahap mistis yaitu terjaga di malam hari dalam keadaan gelap, puasa mutih dan puasa pendem. Ritual ilmu perdukunan tersebut kemudian diritualkan pada waktu tertentu yaitu kamis malam jumat manis dan selasa wage dalam penanggalan Jawa.

Tremmel (1975) dalam La Ode (2012) mengatakan bahwa, umumnya ritual dapat dikatakan berfungsi memperlancar perubahan jiwa atau rohani dalam diri seseorang, membangun hubungan komunikasi antar anggotanya dan Tuhan. Senada dengan Tremmel (1975) di Desa Sidodadi ritual dan pengobatan tradisional dipercaya oleh dukun sebagai alternatif tolak balak yang memungkinkan manusia dapat terhindar dari penyakit, contohnya ruwatan. Hal tersebut telah dipercaya secara turun temurun dapat mencegah berbagai penyakit yang diakibatkan oleh makhluk halus. Tindakan pemujaan melalui ritual adat dilakukan dalam penghormatan kepada leluhur dan untuk meminta keselamatan.

Penghormatan leluhur memainkan peranan penting dalam perdukunan di Desa Sidodadi. Leluhur dianggap sebagai pembimbing elmu perdukunan yang dimiliki, leluhur juga dipercaya masih hidup dan kerap pulang ke rumah. Kepercayaan akan kehadiran leluhur menjadikan kebiasaan untuk menyajikan sandingan dengan sajian makanan dan minuman yang disukai oleh orang yang meninggal tersebut. Seseorang yang menginjak jejak barang alus akan mengakibatkan dirinya sakit. Meski sebenarnya tidak ada orang yang ingin sakit maupun menginjak barang alus yang tidak kasat mata, namun kerap kali pujonggo atau wong tuwek menganggap kesakitan tersebut akibat dari kejahatan (keteledoran, tidak mengucapkan amit atau permisi dan bermain sembarangan di tempat angker). Selain itu juga upacara, upacara yang dimaksudkan dalam konteks dukun di Desa Sidodadi yaitu upacara adat pernikahan, khitanan dan lain sebagainya. Sehingga nilai sosial budaya yang dipercaya oleh seorang dukun yaitu bentuk selamat atau pembersihan diri dari hal-hal yang diangap jahat dan mengakibatkan sakit dapat ditangani dengan pengobatan dan melakukan ritual ruwatan.

Dalam hal ini, perdukunan yang telah teregenerasi menjadi suatu ritual yang memiliki simbol di dalamnya. Sajen dalam ritual terdiri dari bermacam-macam bahan yang memiliki makna, semisal pisang raja dianggap sebagai harapan untuk kepemimpinan, kue apem sebagai permintaan maaf, kemenyan sebagai penghantar doa-doa yang diharapkan adalah simbol yang memiliki makna sebagai nilai-nilai budaya. Kepercayaan menjaga tingkah laku di tempat-tempat angker untuk menjaga kesehatan dari karma penyakit adalah bentuk norma budaya yang telah disepakati bersama untuk membatasi keteraturan diri dengan lingkungan. Ritual-ritual yang dilakukan dalam masyarakat yang dipandu oleh dukun spesialis adalah bentuk sistem sosial yang telah dilakukan untuk menjaga harmonisasi sitem dan interaksi dari sejumlah aktor lainnya.

Pada pewarisan dukun di Desa Sidodadi, agama, kepercayaan dan laku mistik saling berkaitan untuk membentuk kekuatan batin sebagai hasil dari proses ngelmu perdukunan. Agama yang diyakini oleh seorang dukun dianggap sebagai dasar dari nilai keyakinannya dengan Tuhan sedangkan kepercayaan terlihat sebagai bentuk dari respon terhadap budaya dan adat yang teregenerasi sebelumnya. Bentukbentuk kepercayaan yang telah menjadi darah daging akan terus dituturkan dan dilakukan kepada regenerasi berikutnya, salah satunya dalam tata cara perayaan ritual adat dengan mempersiapkan hari baik dan isian sajen.

Pewarisan dukun salah satu bentuk warisan budaya yang dilakukan oleh wong tuwek ataupun pujonggo desa adalah bentuk pemeliharaan ilmu perdukunan antar generasinya. Arafah (2013) mengatakan pewarisan budaya yaitu proses mewariskan budaya (unsur-unsur budaya) dari satu generasi ke generasi manusia atau masyarakat berikutnya melalui proses pembudayaan (proses belajar budaya).

Senada dengan Arafah (2013) proses pewarisan dukun juga merupakan proses pewarisan budaya. Setiap regenerasi diajarkan melalui kebiasaan perihal praktik perdukunan. Pembudayaan tersebut didalami lagi dengan memahami religiusitas keimanan dalam ngelmu perdukunan. 
Pada ilmu perdukunan terdapat pewarisan keyakinan dan kepercayaan. Tindakan-tindakan keyakinan dan kepercayaan tersebut biasanya dikaitkan dengan bentuk mitos dan ritual adat. Dhavamoni (1995), mengatakan ritual adat tidak akan jauh dari agama dan keyakinan yang mana keyakinan-keyakinan dan praktik religius hanyalah sebagian tata cara manusia, dengan mana ia mencoba mengungkapkan dan mewujudkan keharmonisan antara individu dan keseluruhan ini (alam semesta).

Yusuf (1989) menerangkan dalam praktek perdukunan, sebagian besar dukun mempergunakan bantuan kekuatan spiritual yang berhubungan dengan kuasa supernatural. Mereka percaya bahwa kekuatan itu akan dapat memperlancar pekerjaannya. Senada dengan Yusuf (1989), sebagian dukun di Desa Sidodadi memiliki roh, jin, maupun leluhur yang diminta untuk membantu jalannya perdukunan. Kekuatan-kekuatan roh dan jin tersebut di luar nalar manusia biasa yang dapat dipahami sebagai kekuatan supernatural. Pada dukun Desa Sidodadi kekuatan supernatural tersebut berada di ranah Pujonggo, tyang saget dan dukun gamboh yang mana ketiganya menjadi penolong kesurupan atau kerasukan yang membutuhkan perewangan untuk berkomunikasi dengan roh, jin atau barang alus yang memasuki jiwa pasien si dukun.

Pada lingkup stuktur sosial, Sosrodihadjo (1970) dalam Yusuf (1989) mengatakan, barang siapa yang menduduki tempat yang tinggi di dalam struktur masyarakat itu, dia pula yang mempunyai kekuasaan dan pengaruh yang besar. Di Desa Sidodadi terdapat keluarga yang dianggap sebagai pemuka adat yang dihargai, salah satunya Trah Bani Sogol. Menurut Sairin (1992) mengenai Jaringan kekerabatan dalam masyarakat Jawa yang sering disebut sebagai "trah". Trah adalah sebuah organisasi yang didasari pada faktor hubungan genealogis. Penjelasan lebih lanjut, bahwa jaringan kekerabatan atau trah berperan dalam hubungan sosial ekonomi, berkaitan dengan perubahan status pada para anggotannya (1992).

Pewarisan ilmu perdukunan di Trah Bani Sogol diterapkan sejak leluhur terdahulu. Saat ini Mbah Katiyah yang sebagai wong tuwek desa juga mewariskan mcam-macam jenis ilmu perdukunan kepada anak dan cucunya. Praktik perdukunan juga dilakukan anak-anak si mbah, meskipun cucunya belum membuka praktik perdukunan akan tetapi turut memahami penyembuhan yang dilakukan dalam penanganan penyakit. Belum cukup usia adalah salah satu alasan cucu si mbah tidak melakukan praktik perdukunan.

Salah satu keluarga yang telah mewariskan ilmu perdukunannya kepada generasinya. Masyarakat menghormati keluarga Trah Bani Sogol sebagai pemuka adat atau wong sepuh desa. Trah Bani Sogol bersumbangsih terhadap kelanggengan ilmu perdukunan. Pengetahuan mengenai ngelmu dan pratik perdukunan dilakukan oleh tujuh anak si Mbah dan dua cucunya yang meskipun hanya mengetahui cara praktik perdukunan tanpa menerima pasien. Sehingga hanya tujuh anak si mbah yang masih mempraktekan ilmu perdukunan di Desa Sidodadi bahkan ketika berpindah ke desa lainnya. Trah Bani Sogol yang terdiri dari keluarga Mbah Katiyah memiliki pemahaman tersendiri mengenai perdukunan, sehingga mbah Katiyah mewariskan pengetahuannya secara spesifik. Spesifikasi tersebut terlihat atas perbedaan-perbedaan penguasaan ilmu perdukunan yang dimiliki anak-anaknya.

Pewarisan ilmu perdukunan yang dilakukan oleh Trah Bani Sogol dilakukan dengan bervariasi, ada yang dengan berpuasa, amalan dan dengan cara perewangan. Salah satu proses regenerasi dukun dengan berpuasa pati geni yakni berpuasa 3 hari 3 malam, ketika memasuki waktu maghrib makan nasi putih sebanyak 3 kepalan tangan tanpa lauk dan tanpa perasa (mutih), minum air satu gelas, hingga 3 malam tidak makan. "kui tebusane sewu satus, wetenge di sat, matane di tus"(itu tembusannya seratus. Perutnya dikuras, matanya ditiriskan) tutur Mbah Katiyah. Hal tersebut telah dilakukan oleh Mbah Katiyah sejak muda hingga menjadi kebiasaan saat ini (kepatuh).

Maksud dari perkataan tebusane sewu satus yakni proses ngelmu yang harus dilakukan yakni wetenge disat atau menguras perut yang artinya menahan lapar diperut dengan berpuasa. Puasa yang harus dilakukan juga bermacam-macam sesuai bidang keilmuan yang dibutuhkan. Matane ditus atau meniriskan mata, artinya kita harus menahan kantuk yang berlebih karena salah satu prosesnya yakni melekan atau begadang selama berpuasa sehingga ketika kita menahan mata yang terjaga akan 
meneteskan air mata. Sewu satus adalah istilah yang diberikan oleh pujonggo dukun untuk menjawab orang yang akan meminta ilmu perdukunan.

Selain itu, Menurut Mbah Sogol ilmu perdukunan memiliki dua cara yakni kebatinan dan perewangan di mana keduanya sangat berbeda meskipun tujuannya sama. Ilmu kebatinan adalah ilmu mbatin atau ilmu syorof untuk melihat batin seseorang dalam melihat penyakit dan penyembuhan. Istilah amalan menurut orang Jawa dianggap sebagai rapal yang juga memiki arti bacaan sedangkan istilah santri adalah wirid. Perewangan adalah salah satu unsur ilmu perdukunan yang dibantu oleh roh. Roh yang membantu tergantung si pemilik ilmu entah dari buyut yang sudah meninggal dan mempunyai ilmu perdukunan maupun dari pujonggo. Meskipun kedua unsur tersebut berbeda namun untuk pelaksanaan proses regenerasi ilmu perdukunan masih sama yaitu menggunakan puasa dan amalan.

Pewarisan ilmu perdukunan memang tidak dapat diketahui oleh orang awam karena menurut Pak Sudir nantinya akan ditakutkan adanya penyalahgunaan maupun penyepelehan ilmu perdukunan. Pewarisan ilmu perdukunan juga memiliki syarat khusus yang telah dipercaya sejak keturunan terdahulu. Syarat pertama yakni tidak sombong. Seorang dukun tidak diperbolehkan untuk menyombongkan dirinya. Calon dukun yang masih muda dinggap kurang dapat bersungguh-sungguh dalam menjalankan ngelmu perdukunannya, yang mana masih memiliki sikap labil dan diwaspadai dapat menyombongkan diri atas kemampuannya. Sikap tersebut dianggap akan mempermalukan si guru dukun dan akan dicap "sok tahu" oleh dukun lainnya.

Seorang dukun juga tidak diperbolehkan mengajarkan ilmu perdukunan kepada seseorang yang belum memiliki cucu dipercaya dapat mengakibatkan seorang calon dukun tersebut mati muda. Alasan tersebut dianggap sebagai kepercayaan yang telah dipercaya sejak leluhur terdahulu. Selain itu, seorang dukun juga tidak diperbolehkan untuk memperjual belikan ilmu perdukunannya serta dapat benar-benar melakukan kebiasaan praktek perdukunan yang tidak boleh ditulis akan tetapi dihafalkan secara berangsur-angsur tiap harinya.

\section{Simpulan}

Penelitian ini membahas mengenai pewarisan ilmu perdukunan yang didominasi oleh keturunan. Pada proses pewarisan ilmu perdukunan didasari oleh keyakinan dan kepercayaan akan adanya religiusitas dan mitos yang dipercaya melalui kebiasaan. Keyakinan dan kepercayaan seorang dukun terintepretasikan melalui ritual dan laku mistik dalam proses ngelmu perdukunan. Proses ngelmu perdukunan dalam keturunan dapat saling berpengaruh dengan kepercayaan yang dilakukan melalui ritual adat secara turun temurun. Keyakinan dan kepercayaan memegang peranan penting dalam proses ngelmu perdukunan. Terdapat siklus di mana dukun di Desa Sidodadi menerapkan pengetahuan perdukunanannya kepada anak-anaknya atau keturunannya, yang kemudian dipercayai oleh generasinya dalam bentuk mitos dan praktik pengobatan yang dimiliki keluarga terdahulunya.

\section{Daftar Pustaka}

Alwisol (1989) Dukun, Mantera dan Kepercayaan Rakyat. Jakarta: PT. Pustakarya. Grafikatama.

Arafah B (2013) Warisan budaya, pelestarian dan pemanfatannya. [Diakses pada 3 April 2016] http://kebudayaan.kemdikbud.go.id/wp-content/uploads/sites/46/2013/10/burhanuddinarafah_warisan-dan-pewarisan-budaya_unity-in-diversity_warisan-budaya-pelesatrian-danpemanfaatannya-.pdf.

Aris LO (2012) Fungsi ritual Kaago-Ago (ritual pencegah penyakit) pada masyarakat Muna di Sulawesi Tenggara. Jurnal Komunitas 4 (1):1-11.

Danandjaja J (2002) Folklor Indonesia: Ilmu Gosip, Dongeng, dan lain-lain. Jakarta: Pustaka Utama Grafiti.

Dhavamony M (1995) Fenomenologi Agama.Yogyakarta: Kanisius.

Endraswara S (2003) Mistik Kejawen: Sinkretisme, Simbolisme, dan Sufisme, dalam Budaya Jawa. Yogyakarta: Narasi. 
Endraswara S (2003) Metodologi Penelitian Kebudayaan. Yogyakarta: Gadjah Mada University Press.

Foster \& Anderson (1986) Antropologi Kesehatan. Jakarta: UI Press.

Kasnodihardjo (2012) Etnik Jawa Desa Gading sari, Kecamatan Sanden, Kabupaten Bantul. Seri Etnografi Kesehatan Ibu dan Anak. Yogyakarta: Kanisius.

Rienks AS \& Purwanta I (1985) Penyakit dan Pengobatan di Jawa Tengah: Persepsi Desa Kontra Persepsi Pemerintah. Dalam: M.R.Dove (ed). Peranan Kebudayaan Indonesia dalam Modernisasi. Jakarta: AAI dan Yayasan Obor.

Sjafri S (1992) Javanese Trah: Kin-Based Social Organization. Yogyakarta: Gadjah Mada University Press.

Sianipar (1989) Dukun, Mantra dan Kepercayaan Masyarakat. Jakarta: Pustakakarya Grafikatama Spradley JP (1997) Metode Penelitian Etnografi.Yogyakarta: Tiara Wacana.

Syuhudi IM, Sami MY \& Said MB (2013) Etnografi Dukun: Studi Antropologi Tentang Praktik Pengobatan Dukun di Kota Makassar. Makasar: Balai Penelitian dan Pengembangan Agama Makassar.

Yusuf M (1989) Dukun, Mantera dan Kepercayaan Rakyat. Jakarta: PT. Pustakarya Grafikatama. 